\title{
EFFECTS OF THE EXTRACT OF CALOPHYLLUM INOPHYLLUM ON BEHAVIORAL INDICES IN RODENTS
}

\author{
Received December 10, 2013
}

We examined modifications of behavioral indices evoked in rodents by introduction of an alcohol extract from leafs of Calophyllum inophyllum (C.i.) under conditions of four neurobehavioral tests. Intraperitoneal injections of 50,100 , or $200 \mathrm{mg} / \mathrm{kg}$ of the concentrated extract were used; the effects observed were compared with the action of $1 \mathrm{mg} / \mathrm{kg}$ diazepam. In the hole-board test, injections of the C.i. extract significantly suppressed the manifestations of research behavior (decreased the number of head dips into openings) in a dose-dependent manner. In the light/dark box test, considerable increases of the time of stay of mice in the dark compartment were observed after extract injections. In the open field test on mice, injections of the C.i. extract resulted in noticeable, while statistically insignificant, decreases in the general intensity of locomotion (number of crossed squares). In this test, the number of manifestations of research behavior (rearings) decreased rather considerably; the number of grooming episodes also became smaller, but suppression of this type of behavior was weaker. Testing of rats in the elevated plus-maze showed that the numbers of entries of the animals into open arms of the labyrinth significantly decreased at all doses of the extract, and the duration of stay in these arms was also smaller. Thus, the extract from the C.i. leafs containing significant amounts of biologically active compounds demonstrates rather considerable sedative effects, but these effects are combined with some anxiogenic action. The results obtained also show that anxiolythic/anxiogenic effects of a given test agent observed in different behavioral tests (considered specific from this aspect) are not fully identical and should be compared with reservations.

\section{Keywords: sedation, anxiogenics/anxiolytics, exploratory behavior, locomotion.}

\section{INTRODUCTION}

Calophyllum inophyllum (C.i.) belongs to the family Clusiaceae. It is an evergreen tree found in the tropical areas of Africa, America, and Asia [1]. The tree is medium-sized ( 8 to $20 \mathrm{~m}$ in height), with a broad crown formed by irregular branches. Its wood is used in carving, cabinet making, and boat building. The leaves are dark green, shiny, and hairless, with bold elliptical blades.

Phytochemical analysis of the material obtained from this plant revealed that it contains polyunsaturated fatty acids, lipoproteins, coumarins, flavonoids, tocopherols, tocotrienols, and xanthones [2]. In earlier reports, it was mentioned that the fresh bark of C.i. is

\footnotetext{
${ }^{1}$ Department of Physiology, College of Medicine, University of Ibadan, Nigeria.

Correspondence should be addressed to G. F. Ibironke

(e-mail: gibironk@yahoo.com).
}

used for the treatment of diabetes [3], while its fresh fruits are used in the case of rheumatism [4]. It was also reported that the respective remedies have antineuralgic activities [5]. Based on the ethnobotanical and pharmacological reports mentioned above, we hypothesized that an extract obtained from C.i. could exert certain effects on the CNS, and administration of this extract could result in some behavioral modifications. To test this hypothesis, we evaluated the CNS-controlled behavioral activities in mice and rats subjected to injections of the C.i. extract, using several behavioral tests.

\section{METHODS}

Plant Material and Preparation of the Extract. The leaves of the plant were collected from the Botanical Garden of the University of Ibadan, Nigeria. Preliminary identification and authentication of the 
plant were performed according to the herbarium of the Department where a voucher specimen with reference No. FHI 106877 was deposited for future reference.

The leaves were shade-dried at room temperature for about 2 weeks and then ground in an electric mill (to obtain particles below $4 \mathrm{~mm}$ in diameter). This material $(3 \mathrm{~kg}$ ) was extracted by maceration in $60 \%$ ethanol at $50^{\circ} \mathrm{C}$ for $2 \mathrm{~h}$. The extraction procedure was repeated once again under the same conditions with a new portion of the solvent. Extracts were then filtered through a Wattman No. 1 filter paper and concentrated using a rotary evaporator under reduced pressure. The yield of the extract was quantified (14.45\%), and the material obtained was stored in darkness in a refrigerator at $4{ }^{\circ} \mathrm{C}$ until its using in the experiments.

Diazepam (F. Hoffmann-La Roche, Switzerland) was used as a reference drug (positive control) for estimation of the intensity of anxiolytic activities.

Animals. Male albino Swiss mice (25-30 g) and albino rats (220-250 g) were used for the study. Animals were obtained from the Pre-clinical Animal House of the College of Medicine, University of Ibadan, Nigeria. Animals of both species were housed six per cage and kept during at least 7 days prior to the pharmacological experiments, with free access to water and standard rodent pellet food, at a 12/12 h light/dark cycle and room temperature [6]. Each experimental group consisted of at least six animals.

Behavioral observations took place in a soundproof room, at the same period of the day (to reduce the influence of diurnal variations on spontaneous behavior). Each animal was tested only once.

Treatment. The C.i. extract was freshly dissolved in distilled water before administration. Doses of the extract and time intervals were determined in preliminary tests. Diazepam $(1 \mathrm{mg} / \mathrm{kg})$ was dissolved in $40 \%$ propylene glycol. After i.p. administrations were performed, animals were subjected to behavioral tests after a 30 -min-long interval.

Behavioral Tests. Hole-board test. A hole-board apparatus $(35 \times 35 \times 15 \mathrm{~cm})$ with 16 evenly spaced holes [7] was used for tests on mice; the number of examinations of the holes within the observation period was considered a correlate of the intensity of exploratory behavior. Mice were grouped $(n=6)$ and treated with saline $(10 \mathrm{ml} / \mathrm{kg})$, or extract $(50,100$, and $200 \mathrm{mg} / \mathrm{kg}$ ), or diazepam $(1 \mathrm{mg} / \mathrm{kg})$. Thirty min later, the mice were placed singly on the board and the number of events where the mouse dipped its head into the hole within a 5-min-long interval was counted [8].

Light/Dark Box Test. The box included two compartments, a small dark "safe" one (one third) of the entire volume of the box, and a large illuminated aversive compartment (two thirds). Experimental mice were grouped $(n=6)$ and treated with saline $(10 \mathrm{ml} / \mathrm{kg})$, C.i. extract $(50,100$, and $200 \mathrm{mg} / \mathrm{kg})$, or diazepam $(1 \mathrm{mg} / \mathrm{kg})$. Thirty min later, the mice were placed in the lit compartment and allowed to move freely through the opening between the two compartments. The number of transitions between these compartments and total time spent in each compartment were recorded for $5 \mathrm{~min}$.

Open Field Test. A standard set was used for the open field test on mice. A rectangular arena with a hard floor $(36 \times 36 \times 26 \mathrm{~cm}$ with $26-\mathrm{cm}$ walls $)$ was made up of white painted wood. The arena was divided by permanent red markings into 16 equal squares. Spontaneous motor activity was monitored for $30 \mathrm{~min}$ [9]. After various treatments explained earlier, each mouse was put into the field, and the total locomotion index (number of squares crossed with four limbs), rearing frequency (number of times the animal stood on its hindlimbs, with four limbs against the walls of the observation chamber or free in air), and frequency of grooming (number of body cleanings with the paws, picking of the body and pubis with the mouth and face washing episodes) were recorded within 10-min-long observation periods. The arena was then cleaned with $70 \%$ alcohol to eliminate olfactory bias and allowed to dry before introduction before placing of another animal.

Elevated Plus-Maze Test. This test has been widely used to measure the anxiety level in rodents $[10,11]$. For tests on rats, the apparatus constructed from Plexiglass consisted of two open arms $(50 \times 10$ $\mathrm{cm}$ each), two enclosed arms $(50 \times 10 \times 40 \mathrm{~cm}$ each $)$, and a central platform $(10 \times 10 \mathrm{~cm})$, arranged in such a way that two arms of each type were opposite to each other. The maze was elevated $70 \mathrm{~cm}$ above the floor. Thirty min after the i.p. treatment with the C.i. extract $(50,100$, and $200 \mathrm{mg} / \mathrm{kg})$, or diazepam $(1 \mathrm{mg} / \mathrm{kg})$, or saline $(10 \mathrm{ml} / \mathrm{kg})$, each rat $(n=6)$ was placed at the centre of the maze facing one of the enclosed arms. During the 5-min-long test period, the number of open and closed arm entries and the time spent in each of these arms were measured. An entry into the arm was defined as the event where the rat placed all four paws into this arm. After the test, the maze was carefully cleaned with $70 \%$ alcohol solution to eliminate olfactory bias.

Statistical Analysis. The numerical data were analyzed and expressed as means \pm s.e.m. for the 
mentioned five animal groups. Statistical comparison was done using the Student's $t$-test. Intergroup differences with $P<0.05$ were considered significant.

\section{RESULTS}

Hole-Board Test. Introduction of the C.i. extract induced decreases in the number of head dips performed by experimental mice within the 5-minlong observation period of this test. The effects demonstrated the clear dose dependence. At a $50 \mathrm{mg} / \mathrm{kg}$ dose, the drop was obvious but did not reach the significance level $(P>0.05)$. At higher doses of the extract, changes in the number of head dips (i.e., manifestations of exploratory behavior) were highly significant. At 100 and $200 \mathrm{mg} / \mathrm{kg}$ doses, the respective indices were only about 41 and $26 \%$ of the control value $(P<0.01$ and $P<0.001$, respectively). Introductions of the reference drug diazepam also resulted in more than threefold decrease in the mean number of head dips $(P<0.01)$ (Fig. 1).

Light/Dark Box Test. Mice subjected to injections of the C.i. extract demonstrated significantly greater values of the time spent in the dark compartment of the chamber. The respective normalized increments, as compared with the control, were 61,81 , and $108 \%$ at 50,100 , and $200 \mathrm{mg} / \mathrm{kg}$ doses of the extract

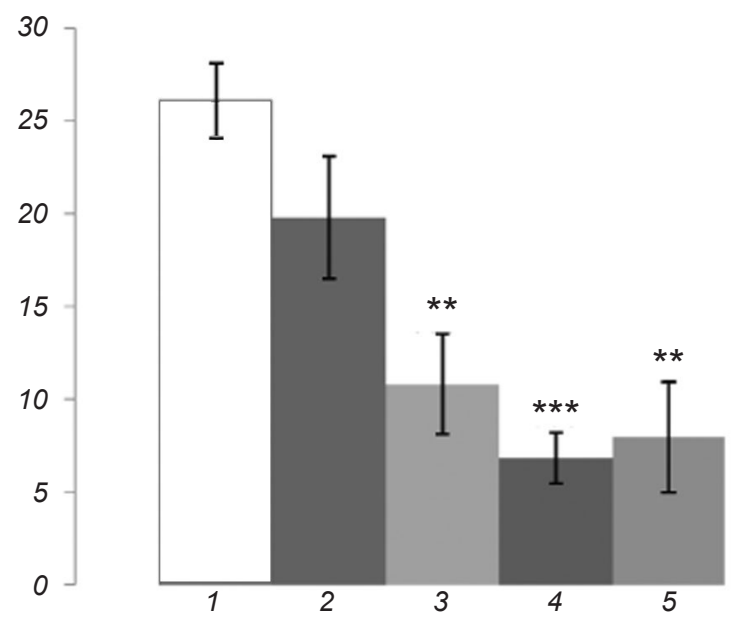

F i g. 1. Diagram of the effects of graded doses of the ethanol leaf extract of Calophyllum inophyllum (C.i.) on the number of head dips in the hole board test on mice. 1) Control, 2-4) injections of the extract, 50,100 , and $200 \mathrm{mg} / \mathrm{kg}$, respectively, 5) injections of $1.0 \mathrm{mg} / \mathrm{kg}$ diazepam. $* *$ and $* * *$, differences from the control are significant whith $P<0.01$ and $P<0.001$, respectively.

P и с. 1. Впливи екстракту з листя калофілума на дослідницьку поведінку мишей в умовах тесту з дошкою з отворами.
$(P<0.05, P<0.01$, and $P<0.001$, respectively $)$. Diazepam injections also resulted in significant prolongation of the "dark compartment" stay $(P<0.001)$ (Fig. 2).

Open Field Test. All doses of the C.i. extract suppressed somewhat the locomotion component of behavior observed under conditions of this test. At the highest dose of the extract, the decrement in the mean number of crossed squares was about $40 \%$, as compared with the control value. Nonetheless, all these shifts did not reach the significance level $(P>0.05$; perhaps, mostly because of high dispersions of the individual values). There was some trend toward the dose dependence of the effects observed, but it was much less clear than that observed in the two former tests. Injections of diazepam exerted practically no influence on the intensity of locomotor activity (Fig. 3A).

In mice injected with the C.i. extract, intense suppression of the orientation/research behavior (manifested in drops in the frequency of rearings) was observed. The respective decreases were significant at all doses of the extract tested (at 50,100, and $200 \mathrm{mg} / \mathrm{kg}$, $P<0.01, P<0.01$, and $P<0.001$, respectively). Certain trend toward the dose dependence of the effect on this index could be also noted. After injections of diazepam, the mean number of rearings within the observation period of the open field test was more than two times smaller than that in the control (Fig. 3B).

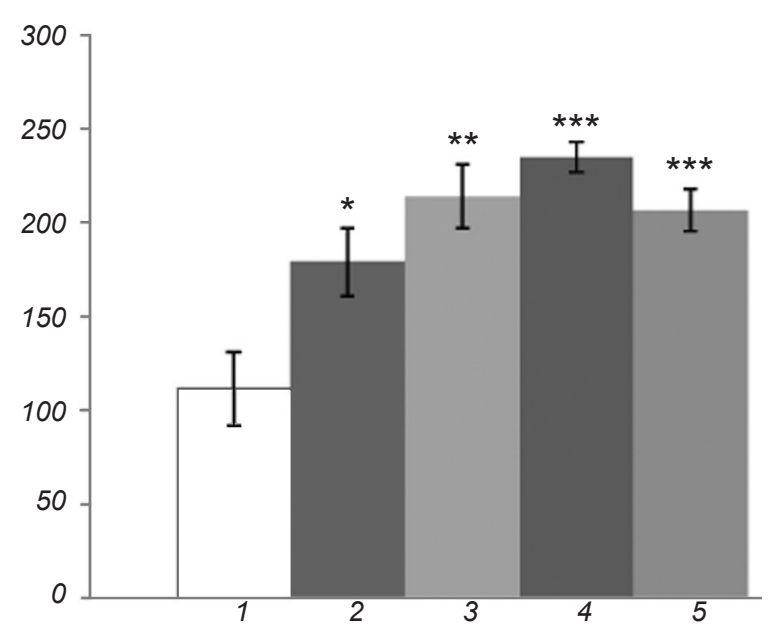

F i g 2: Diagram of the effects of the extract of Calophyllum inophyllum on the time spent in the dark compartment of the light/dark box in mice. $* P<0.05$ compared with the control. Other designations are the same as in Fig. 1.

P и с. 2. Впливи екстракту з листя калофілума на поведінку мишей в умовах тесту 3 камерою 3 освітленим та темним відсіками. 


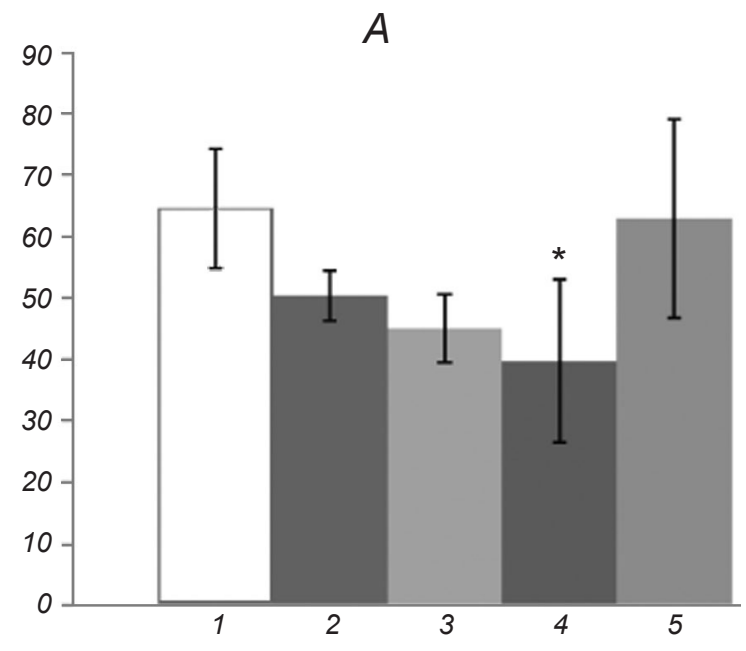

F i g 3: Diagram of the effects of graded doses of ethanol leaf the extract of Calophyllum inophyllum on behavioral indices in the open field test. A) Intensity of locomotion (numbers of crossed squares); B) frequency of rearings; C) grooming frequency. Designations are similar to those in Figs. 1 and 2.

P и с. 3. Впливи екстракту з листя калофілума на локомоторну активність $(A)$, частоту вертикальних стійок $(B)$ та частоту епізодів грумінгу $(C)$ у мишей в умовах тесту відкритого поля.

The number of grooming episodes was also affected by treatment with the C.i. extract. In general, the frequency of grooming episodes decreased. At low and medium doses of the extract (50 and $100 \mathrm{mg} / \mathrm{kg}$ ), the decrements did not reach the significance level $(P>0.05)$. At the $200 \mathrm{mg} /$ $\mathrm{kg}$ dose, however, a more than twofold drop in this index was observed, and the difference was significant. Injections of diazepam suppressed somewhat (by about $30 \%$, on average) the grooming component of behavior in the open field, but the

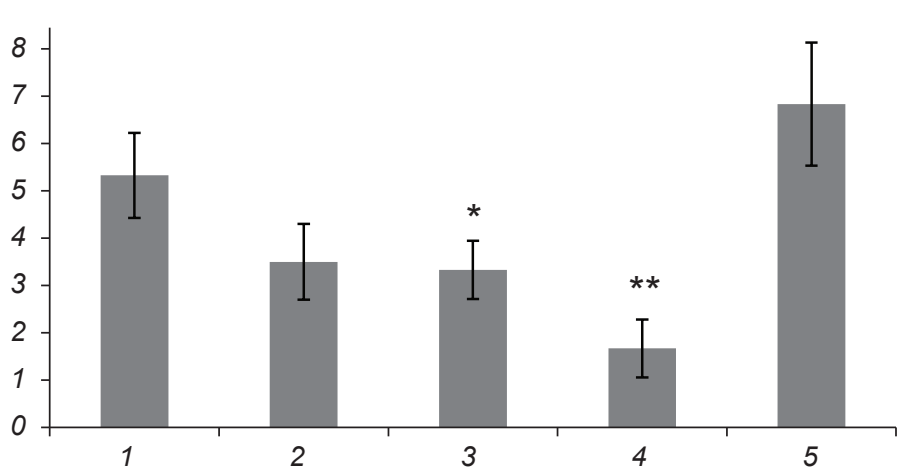

F i g. 4. Diagram of the effects of the C.i. extract on rats in the elevated plus-maze test. Vertical scale) Number of entries into the open arms within the observation period. Other designations are similar to those in Figs. 1-3.

P и с. 4. Впливи екстракту з листя калофілума на поведінку щурів у тесті з піднятим лабіринтом.
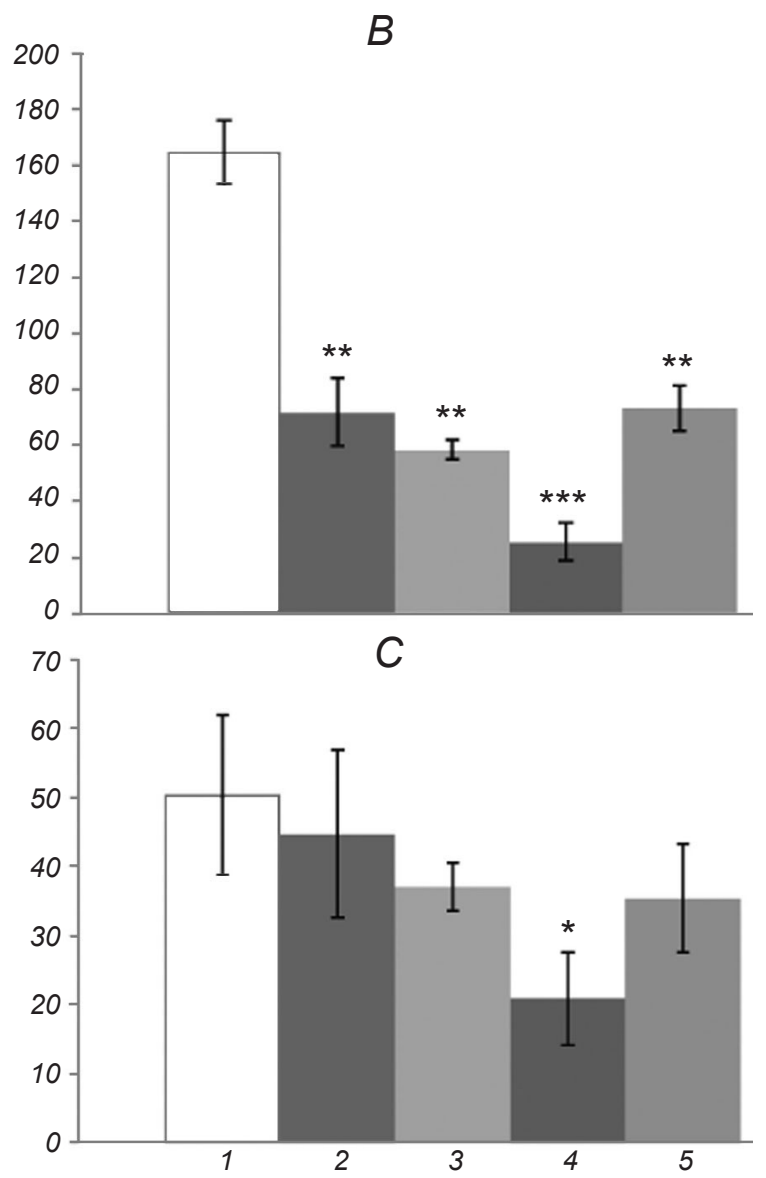

difference did not reach the significance level $(P>0.05)$ because of high interindividual variability of the respective values (Fig. 3C).

Elevated Plus-Maze Test. All doses of the extract used provided noticeable decreases in the number of entries of rats into the open arms and time spent in these arms. At a $50 \mathrm{mg} / \mathrm{kg}$ dose, the drop in the number of entries was about $35 \%$, but the difference was insignificant. At higher doses (100 and $200 \mathrm{mg} / \mathrm{kg})$, the decrements were 38 and $70 \%$ $(P<0.05$ and $P<0.01$, respectively). Injections of diazepam resulted in a noticeable increase in the number of entries into the open arms (about 28\%), but the difference did not reach the significance level because of high individual variability of the values.

\section{DISCUSSION}

Our study provided evidence that the ethanol extract of C.i. leaves contains significant amounts of psychoactive substances mostly sedative in their nature. Though the extract insignificantly $(P>0.05)$ 
decreased locomotion activity in the open field test, decreases observed in the rearing frequencies (orientation/research behavior) were significant at all dose levels $(P<0.01$ at 50 and $100 \mathrm{mg} / \mathrm{kg}$ doses, and $P<0.001$ at $200 \mathrm{mg} / \mathrm{kg}$ ). These observations taken together with the fact that there was significant $(P<0.05)$ reduction in the grooming frequency $(\mathrm{a}$ correlate of the level of emotionally) at the $200 \mathrm{mg} / \mathrm{kg}$ dose of the C.i. extract points towards a noticeable central sedative effect. According to Masur et al. [12] and Morais et al. [13], locomotion and rearing activities in the open field test are functions of the general CNS excitability, while grooming activity is related to the state of the emotional sphere. Because the C.i. extract demonstrated certain selectivity of its effects on research behavior and emotion-related manifestations, these effects should be considered sedative.

The results of the hole-board test are considered a measure of the intensity of exploratory behavior. An agent that decreases this parameter can be classified as a sedative mean [10]. Certain doses of anxiolytics were shown to increase the number of head dips in the hole-board test [14]. This is a further confirmation of the sedative nature of the extract under study, but the respective effects are combined with some anxiogenic action, since a decrease was observed in the number of head dips. The extract diminished in a dose-dependent mode the exploratory behavior in mice, thereby suggesting that the extract possesses a more clearly expressed sedative potential rather than an anxiolytic one. A probable explanation of this observation is based on the results of phytochemical studies of C.i. showing the presence of significant amounts of xanthones which has been shown to have a sedative effect [15].

The light/dark box test is based on the innate aversion of certain rodents to brightly illuminated areas and also demonstrates changes in spontaneous exploratory behavior. The test is useful to predict anxiolytic-like or anxiogenic-like activity of the tested animals. This test demonstrated more clearly that the extract has some anxiogenic-like activity. After injections of the extract, the animals preferred to spend more time in the dark zone compared with the lit areas confirming their higher aversion for brightly illuminated areas. It should be mentioned that the reference drug (diazepam) showed no anxiolytic influence in this test.

The elevated plus-maze represents one of the most widely used animal models for screening anxiogenics [16]. It is based on the natural aversion of most rodents to height and open spaces, and the observed results are sensitive to both anxiolytics and anxiogenics. The anxiogenic effect of the C.i. extract in our study was confirmed by the fact by a clear dosedependent decrease in the time spent in the open arms of the elevated plus-maze compared with the control. It should be emphasized that a classic anxiolytic, diazepam, somewhat increased the above-mentioned indices in the described test.

Therefore, treatment with the ethanol extract from leafs of C.i. significantly modified behavioral indices observed in the four tests used. In general, the respective effects can be classified as sedative but combined, to a certain extent, with some anxiogenic influence. The latter effect is especially clearly manifested in the elevated plus-maze test. The extract significantly decreased the time spent by rats in open arms of the labyrinth and number of entries into these arms. Correspondingly, the injected rats demonstrated greater preference to spent time into closed (dark) arms. These findings are quite comparable with the results obtained in the light/dark box test on mice. Such mixed effects of the extract are probably related to a variety of the active compounds contained in the examined plant.

All tests used in our study are supposed to give certain information on anxiolytic/anxiogenic effects of one tested agent or another. At the same time, it seems probable that the obtained results cannot be interpreted in a simplified "direct" manner. Sedative effects observed in these tests can be, with some reservations, considered close to anxiolytic ones. The observations obtained in the light/dark box test look, from this aspect, contradictory. Increases in the time spent in the dark compartment of the experimental chamber seem to confirm the anxiogenic effect of the extract. A "classic" anxiolytic, diazepam, however, provided significant prolongation of the time spent in the dark, but not in the illuminated, compartment (in other words, the level of anxiety in this case seemed to increase?). At the same time, this drug demonstrated a clear (while not very intense) anxiolytic effect in the elevated plus-maze. Therefore, the results of different behavioral tests, which are supposed as clear manifestations of the anxiolytic or anxiogenic effect of one agent or another, should be interpreted with caution and certain reservations.

All experiments were conducted in accordance with the internationally accepted standards [6].The experimental 
protocol was approved by the Ethical Committee of the Neuroscience Research Unit of the College of Medicine, University of Ibadan, Nigeria. The regulations on the minimum number of animals and duration of observations required to obtain consistent data were strictly adhered to.

The authors, G. F. Ibironke and O. G. Ugege, confirm that the research and publication of the results were not associated with any conflicts regarding commercial or financial relations, relations with organizations and/or individuals who may have been related to the study, and interrelations of co-authors of the communication.

\section{Г. Ф. Ібіронке ${ }^{1}$ О. Г. Угеге}

\section{ВПЛИВИ ЕКСТРАКТУ CALOPHYLLUM INOPHYLLUM НА ПОВЕДІНКОВІ ПОКАЗНИКИ У ГРИЗУНІВ}

\author{
${ }^{1}$ Медичний коледж Ібаданського університету (Нігерія). \\ $\mathrm{P}$ е 3 ю м е
}

Ми досліджували модифікації поведінки, що викликались у гризунів уведенням екстракту з листя Calophyllum inophyllum (C.i.), в умовах чотирьох нейроповедінкових тестів. Використовували внутрішньоочеревинні ін'єкції концентрованого екстракту в дозах 50, 100 та 200 мг/кг; спостережувані ефекти порівнювали 3 дією 1 мг/кг діазепаму. В тесті «дошка 3 отворами» введення екстракту C.i. мишам дозозалежно істотно пригнічували прояви дослідницької поведінки (кількість зазирань в отвори), тоді як у камері 3 темним та освітленим відсіками після ін'єкцій екстракту спостерігалося значне збільшення тривалості перебування цих тварин у темному компартменті. В тесті відкритого поля на мишах ін'єкції екстракту C.i. призводили до помітного, хоча й статистично невірогідного зменшення загальної інтенсивності локомоції (кількості перетнутих квадратів), причому кількість проявів дослідницької поведінки («стійок») зменшувалася дуже істотно. Кількість епізодів грумінгу також ставала меншою, але пригнічення поведінки даного виду було слабшим. Результати тестування щурів у піднятому лабіринті показали, що тривалість перебування тварин у закритих рукавах лабіринту була при всіх дозах екстракту вірогідно більшою, ніж у контролі. Отже, екстракт із листя C.i., котрий вміщує істотну кількість біологічно активних сполук, демонструє значну седативну активність. Ця активність поєднується 3 певною анксіогенною дією. Отримані результати також свідчать про те, що анксіолітичні/анксіогенні впливи певного тест-агента, виявлені в різних поведінкових тестах, не є цілком ідентичними.

\section{REFERENCES}

1. P. F. Stephens, "A review of the Old World species of Calophyllum inophyllum," J. Arnold Arboretorm., 61, No. 2, 117-424 (1980).

2. B. Carratu, E. Federici, F. R. Gallo, et al., "Plants and parts of the plants used in food supplements: An approach to their safety assessment," Ann. 1st Super. Santa, 46, No. 4, 370-388 (2010).

3. D. Holdworth and B. Wamol, "Medicinal plants of the Admiralty Islands, Papua, New Guinea. Part I," Int. J. Crude drug Res., 20, No. 4, 169-181(1982).

4. M. C. Clatchey, "The ethnopharmacopoeia of Rotoma," $J$. Pharmacol., 50, 270-274 (1998).

5. M. Jeanson, "Anti-leprous plants not belonging to the Flacourtiaceae family," Bull. Nat. Soc. Acclimat. (France, 1938).

6. Handbook for the Use of Animals in Neuroscience Research, 1997. http//apu.sfn.org/content/publications

7. R. M. A. Perez, J. A. L. Perez, L. M. D. Garcia, et al., "New pharmacological activity of Solanum nigrum fruits," $J$. Ethnopharmacol., 62, 43-48 (1998).

8. C. Wolfman, H. Viola, A. C. Paladini, et al., "Possible anxiolytic effects of chrysin, a central benzodiazepine receptor ligand isolated from Passiflora coerviea," Pharmacol., Biochem. Behav., 47, 1-4 (1994).

9. A. A. Ajayi and O. E. Ukponmwan, "Evidence of angiotensin II and endogenous opioids modulation of novelty induced rearing in the rats," Afr. J. Med. Sci., 23, 287-290 (1994).

10. S. File and S. Pellow, "The effect of triazol benzo lobenzodiazepines in two animal tests of anxiety and on the hole board," Brit. J. Pharmacol., 86, 729-735 (1985).

11. R. Lister, "The use of plus maze to measure anxiety in the mouse," Psychopharmacology, 92, 180-185 (1987).

12. J. Masur, R. M. W. Martz, and R. A. Carlini, "Effect of acute and chronic administration of Cannabis sativa and (-) $\mathrm{D}^{9}$-transtetrahydrocannabinol on the behavior of rats in an open field arena," Psychopharmacology, 19, 338-397 (1971).

13. L. C. Moraise, S. L. Barbossa-fillio, and R. N. Almeida, "Central depressant effects of reticulline extracted from Octera ductei in rats and mice," J. Ethnopharmacol., 62, 5761 (1981).

14. Y. Ozturk, S. Aydine, K. H. S. Baser, et al., "Effects of Hypericum perforatum and Hypericum calycinum L. extract on the CNS in mice," Phytomedicine, 3, 139-146 (1996).

15. L. Ming-Chin, "Studies on the sedative effect of Cistanche deserticola," J. Ethnopharmacol., 59, 161-165 (1998).

16. H. Takeda, M. Tsuji, and T. Matsumiya, "Changes in head dipping behavior in the hole board test reflect the anxiogenic and/or anxiolytic state in mice," Eur. J. Pharmacol., 350, 21-29 (1958). 